\title{
Valery Gavrilin and Heinrich Heine: Evolution of the Style of Composition
}

\author{
Ksenia Suponitskaya \\ Faculty of Ballet-Masters \\ Russian University of Theatre Arts \\ Moscow, Russia \\ ksenya7467@yandex.ru
}

\begin{abstract}
The article analyses vocal works by Valery Gavrilin based on the poetry by Heinrich Heine. Since the composer's individual vision of Heine poetic intonation is closely connected with the search for his own style, we analyse its evolution through the works of different periods: early period (Lovely Fisher-Maiden; Twin Sapphires Are Thine Blue Eyes), peak period (song cycles First German Notebook, Second German Notebook, romance Lime Blossoms Drunk With Moonlight), and later period (concept of the Third German Notebook). Here, style-forming expressive techniques include conveying images through characters' intonation (term coined by Vyacheslav Medushevsky), unexpected genre combinations, semantic multidimensionality of crosscutting intonations, and unusual synthesis of song and drama.
\end{abstract}

Keywords—vocal cycle; genre; image; lyric character; drama; intonation; author's style

\section{INTRODUCTION}

Finding one's poet may prove challenging for a composer. While admiring the poetry by Marina Tsvetaeva, Gavrilin, however, chose not to put on paper his song cycle based on her poems. The music had already been composed but the author, who always set very high standards, decided against publishing it. Things were different, though, with the poems by Heinrich Heine: they fascinated him from the first lines and excluded any possible doubts as to whether he should "compose or not compose."

As a child, Gavrilin already felt the special, musical nature of this German poet's works and literarily fell in love with his poems, making Heine his "co-author." Many of his pieces are based on Heine's lyrics, and the first of them was created when the author was thirteen, while the last one was being composed in the last years of Gavrilin's life.

\section{CHILDHOOD COMPOSITIONS BY VALERY GAVRILIN AND HIS ACQUAINTANCE WITH HEINE'S POETRY}

In one of his interviews, Valery Gavrilin observed that pure, unspoilt children lived with their spirit rather than with his soul. Speaking about this, he mentioned the ideas of Archbishop Luke (secular name: Valentin Voino-Yasenetsky) who considered the spirit to be a higher substance than the soul, believing that "spiritual energy produced by the heart connects the individual to the whole world" [1].

An acute sensitivity to adults' remarks, a tragic experience of first losses, and the ability to feel compassion: those features make out that special gift of "hearing with the heart", which can only be seen in very delicate persons. Obviously, it goes alongside with the acute perception of music, poetry and visual art...

In his childhood, though, Gavrilin had no idea about his special sensitivity and never thought of becoming a composer: "My mother wanted me to be a veterinarian. Sometimes I even believe I did not necessarily have to become a musician. I would probably have been a good vet and just a musical person", the future classic of Russian music used to say [1].

But things went differently. Gavrilin's father volunteered for the army and was killed in the WWII in 1942. His mother director of the Kubeno-Ozersky orphanage, was arrested in 1950 on false charges. Until she was cleared of all charges after Stalin's death, Gavrilin lived in an orphanage in the village of Kovyrino near Vologda. The orphanage had passionate, dedicated teachers, who often worked for no money, just out of love for children. One of them was Tatyana Tomashevskaya, a talented pianist who, despite her young age, was also a very wise teacher.

She was the first to realise the unique gift of the future author of the famous Notebooks and The Chimes, noticing his passion for poetry along with music, and above all, of course, for poetry by Heine. "Valery always read a lot, borrowing books from the library, To mashevskaya recalled. $<\ldots>$ Often these were poems by Heine. I wondered why was he so fascinated by the great German. Perhaps, back then, he intuitively found some support in the verses about overcoming pain and suffering. Those poems became the first texts for his songs. Their hidden musicality fascinated him and suggested itself how to put it to music" [2].

The folder titled First works by Gavrilin, stored in the family archive, contains photocopies of many works: Polka No. 1 (1951) and Polka No. 2 (1953), Andante (1951), Waltz No. 1 (1952) and Waltz No. 2 (1953) as well as vocal works (choral and solo) composed in 1953: Fishermen, Lovely Fisher-Maiden (Heine's words), Score for Choir and Soloists, 
Miller, Boy and Donkey (full score), A song about a cat (for children's ensemble), Twin Sapphires Are Thine Blue Eyes (a romance to Heine's words), You're not a steamer (comic song).

Gavrilin showed most of his works to Tomashevskaya. "One day he entered the classroom with a shy smile and stopped at the door. He stood silent pressing some sheets of paper against his chest. Then he went to the piano and timidly handed them to me. These were pages from a drawing albu m with a musical staff drawn very smoothly and the neatly-written title: "H. Heine. Lovely Fisher-Maiden. For a voice accompanied by a piano, music by V. Gavrilin." And above this: "I dedicate this to T. D. Tomashevskaya on her birthday. It seems that there is nothing to wish you but good. Is it true?" [2].

So, at his young age of thirteen, Gavrilin turned to the works of this by no means children's poet. The same year, he showed his works to Ivan Belozemtsev, a visiting teacher from Leningrad. Their meeting, indeed, was organized by Tatiana Tomashevskaya. She recollects that Lovely FisherMaiden made a very special impression on the visitor from the capital, although the author himself later described this composition as nothing but a childish, very funny piece of music.

Studying Gavrilin's early works, we can conclude that, despite his late admission to a music school, he perfectly mastered both harmony and form, and, besides, was endowed with a pronounced melodic gift. The latter, of course, was bound to blossom in the peak period works. But even in his childhood, the future author of well-known vocal works had this special skill, the melodic hearing of the verse. In other words, early themes by Gavrilin were deeply inspired by Heine's poetry. Later, Georgy Sviridov said: "You compose music and lyrics together, don't you? This has already got rudimentary, hardly ever used now" [3]. In one of his interviews, the composer later said himself, as if answering Sviridov: "I probably do have some kind of rudiment of that period. I literally create a musical note alongside with a rhy me" [4].

\section{EMERGING AUTHOR'S ST YLE: DRAMA FEATURES OF THE GERMAN NOTEBOOK}

Upon recommendation by Ivan Belozemtsev, Gavrilin moved to Leningrad and entered the comprehensive school of the Conservatory, then to the Conservatory itself. Back then, the young author never thought of creating large-scale song cycles, focusing on instrumental music instead and often imitating Dmitry Shostakovich, the composer whose works he literally knew by heart.

But one of his teachers, Orest Evlakhov, was convinced that "vocal music genres help... students to develop expressive and plastic melodies, emphasizing the dominance of melodic principles in music in general" [5].

Gavrilin could have been expelled from the Conservatory for ignoring vocal genres, so he immediately began looking for poetic sources. In the end, he made his choice, deciding to return to the work of his "childhood poet". In fact, he never forgot the works of Heinrich Heine, reading and rereading his prose and his poems. The composer had a volume of works by the German author, which he had borrowed from the school library and never returned. Later, he bought a full collection of Heine's works, which got very promptly covered with his remarks.

Perhaps, even in his childhood, when creating Lovely Fisher-Maiden, the future author of the German Notebooks began to understand the folk background of Heine's lyricism that was so close to him. The composer repeatedly noted that "Heine's works refract the intonations of German folklore with its inexplicable power; besides, all kinds of folklore have something in common: simplicity, accessibility, sincerity of feelings, and communication, an obligatory feature" [4]. Here, for the first time in fact (in connection with the German Notebook), Gavrilin reveals his composer's credo: understandable musical language that should be accessible to any audience. "People compose music primarily to be able to communicate, otherwise it is not needed, it becomes meaningless. All the depth of feelings, found in folk music and in folk poetry, is only meant to communicate with those who are around. Thus, starting with this work, the German Notebook, I set communication as my top artistic priority" [5].

The first German Notebook, a work that is independent in its style and clearly showcases the author's identity, was completed in 1962, when the composer was only 23 years old. It was in Heine's poetry that Gavrilin found his unique intonation, which would later be heard in the Russian Notebook and in Military Letters, in The Buffoons and in Three Songs of Ophelia.

His signature features include expressing the images through character's intonation 1 with its figurative and distinctive qualities; semantic multidimensionality; unexpected genre combinations and modulations. To put it short, the colourful, theatrical manner of Gavrilin's thinking was already transpiring in this cycle. (Although finding your way does not necessarily mean pleasing your professor).

Evlakhov strongly disliked The German notebook. Gavrilin, certainly, took his sharply negative opinion as a disaster, he even thought about leaving the Conservatory. However, the popularity of this song cycle (among professional musicians outside the Conservatory) was growing rapidly. And there was something to be fascinated by, indeed. First, by the visual theatre-like nature of the music; second, by the concentration of action around a single character, poet and dreamer, seeking his romantic ideal as if continuing the tradition of Schubert and Schumann.

The character here is multifaceted. The six songs, contrasting and seemingly unrelated, reveal different properties of a romantic nature, such as its vulnerability and

The term 'character's intonation' was coined by Vyacheslav Medushevsky [6]. His concept defines intonation as something 'prominent, with clear-cut bodily and mot or feat ures, small-scale themes, restricted and often contrasting motives, something rounded and faceted with cadences, which correspond to the bodily wholeness and dist inctiveness of the character. 
dreaminess, irony and a predominantly tragic view of life. Implicitly and unobtrusively, the composer unfolds a typical Heine-like story of an unrequited love. The denouement of the tragedy coincides with its culmination: Peter comes to the wedding of his beloved and watches her dancing with her new lover with tears in his eyes (Hans and Grete, the last part of the cycle).

Here, this groaning and yet yelling intonation, accompanied by mechanical "bell-ringing" piano chords, conveys the deep suffering of the romantic character, who takes the loss of his beloved as the loss of the meaning of life. As for the bell theme, it develops from the theme of wedding dance. This technique of cross-genre encoding of intonations would become typical for Gavrilin in the future.

In Dialogue on the Paderborn Heath, for instance, this genre shifting of a trichord chant (from a pastoral song with a bell-ringing touch to a dance tune) is meant to emphasise the opposition of the two Heine characters, one romantic, the other sceptic.

This markedly dramatic manner can be seen in the composer's approach to the text. He defines a certain manner of speech for every character by making them repeat the same phrases, words or rhy mes or by adding some remarks to the initial poetic text.

In many songs, this repetition technique expresses irony. These include Dialogue..., A Worthy Man, Dear Friend. In the latter, the call "Aa-u!", as well as a seven-time repetition of the line "For your heart's flame I behold," and the fourtime repetition of "E'en through your waistcoat burning" are supposed to mock the lovelorn poet.

Indeed, even this very first song cycle by Gavrilin required the performers to demonstrate acting talent along with musical skills.

The triumph of the German Notebook began after it was premiered at the House of Composers on January 20, 1962. The composition was performed by Artur Pochikovsky and Irina Golovneva. Later, The German Notebook was interpreted by Alexander Vedernikov and Natalia Gureeva, Sergey Leiferkus and Irina Golovneva. The cycle was a huge success everywhere, and even Orest Evlakhov, who had long been reluctant to recognize its uniqueness, eventually changed his mind.

\section{ROMANTIC TRENDS IN THE SECOND CYCLE BASED ON POET RY BY HEINE: SYNT HESIS OF SONG AND DRAMA}

Gavrilin saw the success of the German Notebook as something unintentional, mainly belonging to his favourite poet: "It happened merely by accident. I came across the poetry of Heinrich Heine, and suddenly I saw how amazingly wise were the ideas it conveyed and how simply and musically it was written. Since then, Heine has been my highest standard, the very model of the musicality of the verse "[4].

And more: "My dream is to create a Russian opera and a composition based on the excerpt from The Winter's Tale by Heine (a kind of an oratorio with dances and everyday scenes) as seen by a Russian man, who, like everyone else, wants these two nations, so often colliding in destructive wars (by some quirk of fate), to love each other forever, because the spirit of both is great and beautiful and also mutually dependent. This is the spirit of Marx, Heine, Mussorgsky, Haydn, Brecht, and Tchaikovsky <...>" [7].

Gavrilin was arguably the last romanticist in the Russian music. At least, today we see no new dreamers wishing to create an opera based on a Heine plot. There are no followers of Schubert and Schumann songs traditions, either. And the very subject of traditional song cycles (the character's unrequited love and worship of the fair and proud lady, who gave her heart to another man, the collapse of all his hopes and the tragic experience of loneliness) is seen as something old-fashioned. Gavrilin though, once said he did not believe in the modern, interested only in the eternal2. Therefore, his returning to Heine's poetry in 1972, while creating the German Notebook No. 2, was quite logical, as his longstanding fascination by this author had never faded.

When writing the libretto of the Second German Notebook, the composer most probably treated the poet as his co-author. Also, instead of limiting himself to one Russian translation, the composer freely combined different 3 versions, just as he did with the first German Notebook: he seemed to be more interested in the content of the poems rather than in the translation style.

Quite naturally, the second cycle developed every facet of the previous one, adding new details and twists to the love story in order to further stress the tragic disparity between the ideal world imagined by the romantic protagonist and the reality where "she caught in her arms, (oh deluded and dupéd) as husband, the stupidest one of the stupid."

This, of course, required other expressive means. For his new "German performance", the composer acted as a stage director and therefore needed an entire vocal theatre. Interestingly enough, the author himself did not even refer to his work (dedicated to the music expert Arnold Sokhor) as a cycle. Instead, he used the title as follows: "The Second German notebook for voice with a piano.4" In doing so, he emphasized the crucial dramatic role of the instrumental part (for the Notebook contains six (!) independent piano interludes). According to the composer, "This is a fullfledged vocal and piano composition, where the piano is as significant as the voice. <...> The first three interludes are performed by the second pianist from behind the stage. After piece \#10, the singer leaves the stage, and piece \#11 is also performed from behind the stage. If for some reason the second piano cannot be placed behind the stage, then the

\section{Cit. ex. [8].}

3 Russian translations used are by V. Levik, S. Marshak, A. Globa, A. Plescheev, P. Karaban, Y. Tynianov, V. Gavrilin for the First German Notebook; V. Levik, S. Marshak, Y. Tynianov, P. Karp, T. Silman for the Second German Notebook.

4 "The genre here is hard to define, the composer mentioned, as it is composed in a rondo-sonat a form. Essentially, it is a vocal and instrumental sonata, following certain dramatic laws, containing an exposition, a development, and a recapitulation" [3]. 
fourth and fifth interludes, as well as piece \# 11, should be performed on $\langle\ldots\rangle$ another piano onstage" [9].

This description of the musicians' coming and going proves that the composer saw The Second German Notebook as a kind of drama action. Here is Gavrilin's confirmation: "The performance is supposed to include an acting element, he said. It can be accompanied by pantomime to show, depending on the content, military parades, high society dances, or various states of mind: inspiration, meditation, death, etc. <...> Instead of imposing the manner and the development of the performance in terms of dynamics, tempo, intonations, the author relies on the sensitivity and initiative of the performers" [10]5.

The Second German Notebook is, in fact, a second mono-opera by Gavrilin (along with The Russian Notebook). Drama patterns from the Russian Notebook can also be seen here. These include contrasting characters: a romantic hero and his rival, a hussar (the former being dynamic, and the latter static), and a wave-like development, where the culminating peaks pass through the entire cycle. A certain plotline is drawn: the first culmination is the tragedy of losing a lover ("Since my love now loves me not, How to weep I have forgot; Broken is my heart with woe, But my tears refuse to flow"). The second culmination comes when the poet mocks his hussar rival by imitating the sound of a hussar trumpet: tum-tu-ru-ru, tu-ru-ru-tu, tum-tu-ru, and the third culmination point is the departure of the protagonist ("Soon I depart again, and come once more, Then shall I find you neither warm nor cold. And I shall moan lamenting o'er your graves, And mine own heart shall then be poor and cold"). And finally, we see the retrospective plotline, meaning that the outcome of the tragedy is already known at the beginning. Here, like in a movie drama, the outcome and the ending have the same function. Moreover, the final song of the Second German Notebook is based on the theme of the first one: both of them reveal doubts and anxiety of the lyric character, predominant emotions of the cycle.

The tragic reality here is replaced by the immersion in illusions. Suddenly the romantic poet imagines that his beloved one will still become his wife. This gives rise to charming lullaby intonations and unrealistic bell ringing in the music, which makes the inevitable understanding of loneliness even sharper. Just like in the previous Notebook, these sufferings are directed outward. The character appeals to "the whole world", while military officers and hussars (characterized by the march music) become both spectators and participants of the action.

The intonation of the Second German Notebook is based on leading minor thirds, which somehow appear in the themes of most songs and interludes, endowed with mutually exclusive meanings. Their interrogative nature is largely conditioned by unstable harmony (strong beats of each bar corresponding to the harmony of diminished leading-tone sixth chord).

Both remarksthat we quote are quite logically placed in the beginning of the score, serving as a guidance for performers.
In the second part of the ninth song, this leading intonation, shaped as a march, introduces the countercharacter, while in the fifth (piano-only) part, it also conveys the state of fascination and dreaminess.

Like in the first Notebook, the ostinato-like persistent speech patterns are used to emphasise the play. For example, repeated words and rhymes in Hussars Are Blowing Their Trumpets appear as inconsistent agitated speech, depicting the mental turmo il of the character who faces the infidelity of his beloved one: "That were a bo-bo-boisterous household, Landpests and so-so-so-soldiery! And in thy li-li-little heart, dear, The godliest quarters be. For someone. Which one? Which one? Which one?" Generally speaking, the repetition technique, typical for every performing art, finds a wide variety of refractions in the music by Gavrilin. One of its forms is the transfer of themes from one work to another (Gavrilin's favourite method). Another one implies multiple use of the same intonations, words and rhymes within one composition (often even in one part of it), which eventually also became an important component of the composer's style.

The Second German Notebook has been performed by a number of artists. In 1977, The State Music Foundation printed the score on the offset duplicator, but the cycle was not published before 1981. The first edition was performed by the Conservatory professor Boris Lushin and pianist Alexander Kagan (1976). The second edition was brilliantly performed in 1978 by Sergey Yakovenko and Yuri Smirnov.

The composer repeatedly told to Sergey Yakovenko that he could feel perfectly free in his stage acting. As a result, the singer's interpretation deeply impressed Gavrilin himself as well as all the audience: for instance, while performing the song I dreamt I was Almighty God... the famous baritone was lying on the piano.

Later the cycle got noticed by Zara Dolukhanova who began to rehearse it with her students. The work also fascinated the pianist Nelli Tulchinskaya. She staged it with the singer Vladimir Chernov. He performed The Notebook at the Drama Actors' Palace (1988), but soon afterwards he moved abroad, so another concert never took place.

"After quite a long time, Tulchinskaya recalled, after eight years passed, I decided somehow to stage both "German Notebooks"<..> and began rehearsing with the singer Igor Gavrilov. <...> We practiced for four months, five days a week. Fortunately, Valery Gavrilin, appreciated our effort, and we were happy about that" [11]. The concerts took place in Leningrad, Smolensk, Moscow, Vologda, and The German notebooks enjoyed a tremendous success everywhere.

\section{LOST WORK BY VALERY GAVRILIN}

In 1973 to 1975 , Valery Gavrilin was working on the vocal cycle In the Evening, which included Lime blossoms drunk with moonlight 6 , a romance composed earlier on

6 Apart from Heine, this cycle used lyrics by Albina Shulgina, folk verses and those by Gavrilin himself. This work is dedicated to its first performer, Zara Dolukhanova. 
Heine's words. Here, the verses of the German author were integrated in a completely different plot: instead of a romantic character, they are pronounced by an elderly woman who, turning over the pages of an old album, recalls the happy moments of her bygone youth.

This could wrap up our discussion about works based on poetry by Heine, but for one detail: there was also the Third German Notebook subtitled Bimini (after the title of a poem by Heine).

As Gavrilin himself said, referring to his German triad: "The First Notebook is youthful, romantic, some pieces (like Poor Peter) are based on the lyrics previously used by great German composers. This work is about romantic love. The second cycle is the tragedy of a more mature person, reflecting the divergence, the collapse of the world of illusions. Nevertheless, the world is still perceived as full of light. There are reminiscences from Beethoven, Mozart, Schumann, Mahler. Every poem is about failed love, but against the background of reality. Heine here is flanked by all musical classics. The third cycle, Bimini, is an island of fantasy, where everyone is infinitely happy. The form is exactly the same as in the second. This is a composition of hope. This is mature Heine." [3].

So how did Gavrilin's "fantasy island", based on verses from Bimini and other works of He ine, dis appear? Ironically, it happened that this cycle, along with The Wedding, both completely composed and written down, was accidentally thrown out with spare scores when Gavrilin was moving to another apartment in 1996. The composer, very upset about this, decided to restore both works. Basing on remaining drafts, he began to recreate his beautiful country of Bimini anew. However, the composer did not live to complete this work, leaving us only a few lyrics by Heine copied in his neatest handwriting. These include the following verses:

Pretty cradle of my sorrows,

Pretty tombstone of my rest,

Pretty town - we must part,

Farewell! I call to you!

$* * *$

For the land of youth eternal,

For the is land Bimini

I a m yearning, I a m longing;

Friends beloved, fare ye well!

Dear old tabby, Mimili,

Dear old cock, my Kikriki,

Fare ye well, no more shall we

Home return from Bimini!

$* * *$

To my whims I boldly, gladly

Sacrificed my life.
Now I'm lost but have no grief,

For it was my heart's desire!

Thus, by this absurd accident, The Second German Notebook composed in 1972 became the last Gavrilin's large-scale work based on poetry by Heine.

\section{CONCLUSION}

Gavrilin's vocal style was largely influenced by Heine's poetry. It was his poems that encouraged the composer to create his first vocal cycle which clearly showcased his distinct style. Later, it was further developed in the second large-scale work based on Heine's verses, a unique amalgam of singing and drama, resembling a mono-opera in its dramatic structure.

Heine, like Gavrilin, lived a relatively short life, a little less than 60 years. Like the author of The German Notebooks, he was both a realist and a lyricist, capable of acute emotional sensitivity and vulnerability. His poetry was regarded with deep affinity by young Gavrilin, brought up in a Vologda orphanage, despite the epoch difference. It was probably in his childhood that he set up his credo, later put to words: "If something is obviously missing in our time, we must reme mber that it used to exist. There is no romanticis $\mathrm{m}$, chivalry, and unselfishness in today's life, so let them be in music" [12].

\section{REFERENCES}

[1] Valery Gavrilin, Listening with your heart... Articles, Speeches, Int erviews. St. Petersburg, Kompozit or, 2005.

[2] This amazing Gavrilin... / Compiled by Natalia Gavrilina. St. Petersburg, Kompozitor, 2008.

[3] Natalia Gavrilina, Our Life (after diaries and other sources). St. Petersburg, Kompozitor, 2014, pp. 273.

[4] Valery Gavrilin, Listening with your heart....

[5] Orest Evlakhov, Composer and teacher. Articles, Documents, Memories. Leningrad, Sovet sky Kompozitor, 1981, p. 95.

[6] Vyacheslav Medushevsky, Intonation form of music. Moscow, Kompozitor, 1993, p. 71 .

[7] Valery Gavrilin, About music, and beyond... Notes of different years. St. Petersburg, Kompozitor, 2012, p. 212.

[8] Gennady Belov, I set communication as my top artistic priority. In: Valery Gavrilin, Complete works. Vol. XII. St. Petersburg, Kompozitor, 2007, p. 9.

[9] Natalia Gavrilina, Our Life (after diaries and other sources), 2017.

[10] Gennady Belov, I set communication as my top artistic priority

[11] This amazing Gavrilin... p. 230.

[12] Valery Gavrilin, Listening with your heart... Articles, Speeches, Int erviews. St. Petersburg, Kompozit or, 2005. 